\title{
Potential Alteration by Climate Change of the Forest-Fire Regime in the Boreal Forest of Central Yukon Territory
}

\author{
V.M. McCOY ${ }^{1}$ and C.R. BURN ${ }^{1,2}$
}

(Received 28 July 2003; accepted in revised form 9 February 2005)

\begin{abstract}
Statistical relations were obtained to describe the association between forest fires and climate for the Dawson and Mayo fire management districts, central Yukon Territory. Annual fire incidence, area burned, and seasonal fire severity rating were compared with summer observations of mean temperature, total precipitation, mean relative humidity, and mean wind speed. The relations were obtained by multiple regression and combined with regional scenarios of future climate from general circulation models. The strongest statistical associations for fire occurrence and area burned were with temperature and precipitation at Dawson. Depending on the scenario, the statistics suggest that the average annual fire occurrence and area burned may as much as double by 2069 , but there may still be years with few fires. The maximum number of fires may increase by twothirds over present levels, and the maximum area burned per summer may increase to more than three times the present value. Without incorporating changes in climate variability into the scenarios, the year-to-year variability in number of fires is not projected to increase, but the range in area burned per summer may rise by about $15 \%$.
\end{abstract}

Key words: forest fire, wildfire, climate, climate change, Yukon Territory

RÉSUMÉ. On a calculé des rapports statistiques afin de décrire l'association qui existe entre les feux de forêt et le climat pour les districts de prévention des incendies de Dawson et de Mayo, dans le centre du Yukon. On a comparé la fréquence annuelle des feux, la surface brûlée et l'indice saisonnier de gravité d'incendie avec les observations estivales de la température moyenne, de la précipitation totale, de l'humidité relative moyenne et de la vitesse moyenne du vent. Les rapports ont été établis par régression multiple et combinés à des scénarios du futur climat dans la région, scénarios tirés de modèles de circulation généraux. Les associations statistiques dominantes relatives à la fréquence des feux et à la zone brûlée concernaient la température et la précipitation à Dawson. Selon le scénario, les statistiques suggèrent que la fréquence des incendies et la surface brûlée annuelles moyennes pourraient aller jusqu'à doubler d'ici 2069, mais qu'il pourrait toujours y avoir des années où il se produirait peu de feux de forêt. Le nombre maximal de feux pourrait augmenter des deux tiers par rapport aux niveaux actuels, et la superficie maximale brûlée en un été pourrait plus que tripler par rapport à maintenant. Si l'on n'intègre pas aux scénarios des changements dans la variabilité climatique, on ne prévoit pas d'augmentation dans la variabilité annuelle du nombre d'incendies, mais l'étendue de la superficie brûlée en un été pourrait s'accroître d'environ $15 \%$.

Mots clés: feu de forêt, feu irréprimé, climat, changement climatique, Territoire du Yukon

Traduit pour la revue Arctic par Nésida Loyer.

\section{INTRODUCTION}

Forest fires and their management are of considerable interest to residents of northern Canada because of the threats posed to community infrastructure and wildlife populations by fire, opportunities for short-term employment in fire control, and the supply of cordwood and mushrooms from burned areas. Wildfires cause widespread natural disturbance to the boreal forest, but are integral to its ecology: fire is critical in determining forestspecies composition, the regional forest mosaic, vegetation structure in burned stands, and stand productivity (Yarie, 1981, 1983; Johnson, 1992; Weber and Stocks, 1998; Weir et al., 2000; Johnstone et al., 2004). Fire is largely responsible for stand rejuvenation at cold, non- productive sites, as significant nutrient loads are returned to the soil in ash, and destruction of feather mosses leads to soil warming and active-layer deepening (Van Cleve et al., 1991; Mackay, 1995). The intensity of fire influences the light subsequently available at the forest floor, and hence the species composition of the successional community (Van Cleve et al., 1991).

Forest fires play a significant role in the global carbon cycle: boreal ecosystems contain more than $30 \%$ of all the carbon present in terrestrial ecosystems (Kasischke, 2000). Although fire releases approximately $53 \mathrm{Tg}$ (53 million tonnes) of carbon from North American boreal forests each year (Borgeau-Chavez et al., 2000), growth of new vegetation may lead, overall, to these ecosystems' being a net sink for carbon (Kasischke, 2000).

\footnotetext{
${ }^{1}$ Department of Geography and Environmental Studies, Carleton University, 1125 Colonel By Drive, Ottawa, Ontario K1S 5B6, Canada

${ }^{2}$ Corresponding author: crburn@ ccs.carleton.ca

(C) The Arctic Institute of North America
} 


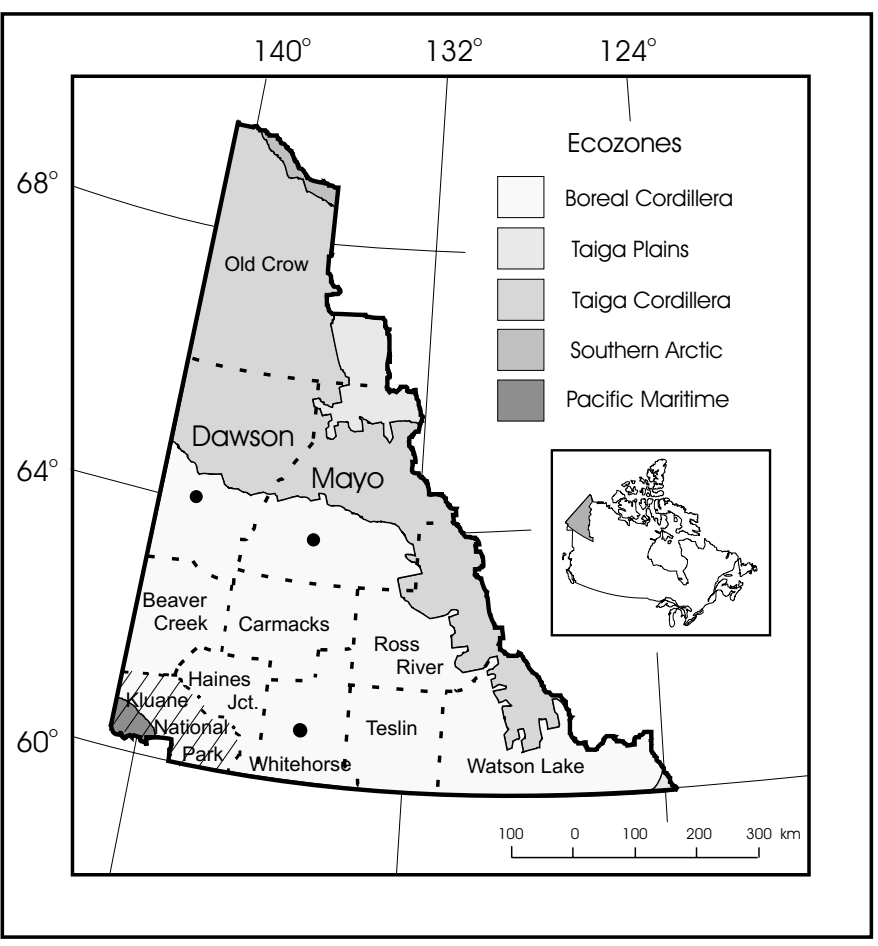

FIG. 1. Ecozones and fire management districts in Yukon Territory (Environment Canada, 2001; fire management districts from D. Milne, Yukon Fire Management, 2001). Yukon Fire Management is not responsible for fire suppression in Kluane National Park.

The relations between weather and forest-fire behaviour are sufficiently well understood that in Canada there is a national Fire Danger Rating System based upon atmospheric conditions (Van Wagner, 1987). However, the associations between wildfire and climate are more general (Nash and Johnson, 1996). For example, maximum fire frequency during the Holocene in Kootenay National Park occurred under the warm and dry conditions of the early to mid-Holocene, 8200 to 4000 yrs BP (Hallett and Walker, 2000), although, in contrast, Lynch et al. (2004) reported an increased fire frequency in SE Alaska under wetter climatic conditions, which they attributed to more frequent lightning strikes and increased seasonal moisture variability. Thus fire-climate relations may vary between climatic regions. Since the end of the 19th century, the fire cycle - the time required to burn an area equal in size to the study area (Johnson and Van Wagner, 1985) - has increased in parts of the boreal forest of western Canada and southern Quebec (Bergeron and Archambault, 1993; Larsen, 1997; Johnson et al., 1999), but not in others (Payette et al., 1989).

The number of forest fires recorded annually in Canada has increased significantly over the last 30 years (Stocks, 1991; Ward and Mawdsley, 2000), with many of the largest fires in the 1980s and 1990s (Weber and Stocks, 1998). Further changes in the fire regime, particularly in terms of frequency and severity, are anticipated throughout the boreal forest as a consequence of climate warming, especially with seasonally warmer or drier conditions, or both (Flannigan and Van Wagner, 1991; Maxwell, 1997; Stocks et al., 1998; Intergovernmental Panel on Climate Change, 2001). General circulation models (GCMs) project that climate change and its associated impacts will be more pronounced in high latitudes than elsewhere (Serreze et al., 2000). For Yukon Territory, the projected increase in mean annual temperature under a doubling of atmospheric carbon dioxide concentration is $2^{\circ}-8^{\circ} \mathrm{C}$ (Hengeveld, 1997).

In Yukon, detailed fire records have been kept for ten fire management districts since 1960. These relatively long and complete series enable determination of statistical relations between climate and fire variables. This study had two objectives: (1) to determine such relations for central Yukon over the period of record and (2) to combine these relations with climate projections, derived from several climate-change scenarios, to assess the potential future regional forest-fire regime. The two fire management districts in central Yukon, which are operationally based at Dawson and Mayo (Fig. 1), were selected for study because of the predominance of fires ignited by lightning in this region, the relatively low proportion of fires that have been fought, and the low human population density, all of which contribute to a relatively natural fire regime (Table 1). These districts are two of the three largest in the Territory (Table 1).

\section{STUDY AREA}

Central Yukon covers approximately $160000 \mathrm{~km}^{2}$, and includes the Ogilvie, Wernecke, Mackenzie, and Selwyn mountains, extensive tablelands dissected by broad, Ushaped valleys, and plateaus incised by $\mathrm{V}$-shaped valleys. The region has a continental climate (Wahl et al., 1987), with the mean annual air temperature at Dawson, $-4.4^{\circ} \mathrm{C}$, lower than that at Mayo, $-3.1^{\circ} \mathrm{C}$ (Environment Canada, 2002). Dawson is colder than Mayo throughout the year, but the difference is smallest in June, July, and August. The mean summer temperatures at Dawson and Mayo are $13.9^{\circ} \mathrm{C}$ and $14.4^{\circ} \mathrm{C}$ respectively. Figure 2 illustrates the high correlation in mean summer temperatures at the two stations throughout the period of common record, 19252000. Annually, Dawson receives about $324 \mathrm{~mm}$ of precipitation, and Mayo $313 \mathrm{~mm}$ (Environment Canada, 2002). Summer is the wettest season at both stations: Dawson receives about $40 \%(131 \mathrm{~mm})$ and Mayo $44 \%(136 \mathrm{~mm})$ of the total annual precipitation during summer. Despite the similarity in average summer precipitation, this variable is not as well correlated at the stations as temperature (Fig. 3).

Central Yukon has three terrestrial ecozones (Fig. 1). The Boreal Cordillera and Taiga Cordillera ecozones cover the majority of the Dawson and Mayo fire management districts. A small portion of the Taiga Plains ecozone also extends into the northeast of the Mayo district. The forest vegetation is dominated by white spruce (Picea glauca), black spruce (Picea mariana), alpine fir (Abies lasiocarpa), 
TABLE 1. Characteristics of Yukon fire management districts, 1960-2000.

\begin{tabular}{|c|c|c|c|c|c|c|c|}
\hline District & $\begin{array}{c}\text { District } \\
\text { Size }\left(\mathrm{km}^{2}\right)\end{array}$ & $\begin{array}{l}\text { Population }^{1} \\
\text { (1998) }\end{array}$ & $\begin{array}{c}\text { Total Number } \\
\text { of Fires }\end{array}$ & $\begin{array}{l}\% \text { Fires in June, } \\
\text { July, and August }\end{array}$ & $\begin{array}{c}\text { Total Area } \\
\text { Burned }\left(\mathrm{km}^{2}\right)\end{array}$ & $\begin{array}{c}\% \text { Fires } \\
\text { not Fought }\end{array}$ & $\begin{array}{l}\text { \% Lightning- } \\
\text { Caused Fires }\end{array}$ \\
\hline Haines Junction & 18489 & 800 & 205 & 69.8 & 195 & 3.4 & 5.9 \\
\hline Whitehorse & 32000 & 23406 & 1359 & 64.6 & 970 & 4.2 & 8.5 \\
\hline Teslin & 25885 & 454 & 188 & 80.8 & 351 & 15.4 & 38.3 \\
\hline Watson Lake & 61156 & 1690 & 586 & 80.2 & 5033 & 24.6 & 54.4 \\
\hline Ross River $^{2}$ & 54472 & 397 & 461 & 84.0 & 5360 & 31.9 & 57.7 \\
\hline Carmacks & 32000 & 461 & 473 & 79.3 & 7959 & 13.7 & 55.8 \\
\hline Beaver Creek & 29867 & 109 & 183 & 82.0 & 1425 & 44.8 & 65.0 \\
\hline Dawson & 76801 & 2057 & 827 & 91.5 & 9193 & 39.3 & 85.2 \\
\hline Mayo & 83485 & 484 & 632 & 94.0 & 9448 & 44.6 & 85.0 \\
\hline Old Crow ${ }^{2}$ & 97992 & 300 & 260 & 93.1 & 6885 & 79.2 & 92.7 \\
\hline
\end{tabular}

${ }^{1}$ Yukon Bureau of Statistics, 2000.

${ }^{2}$ Records from 1962.

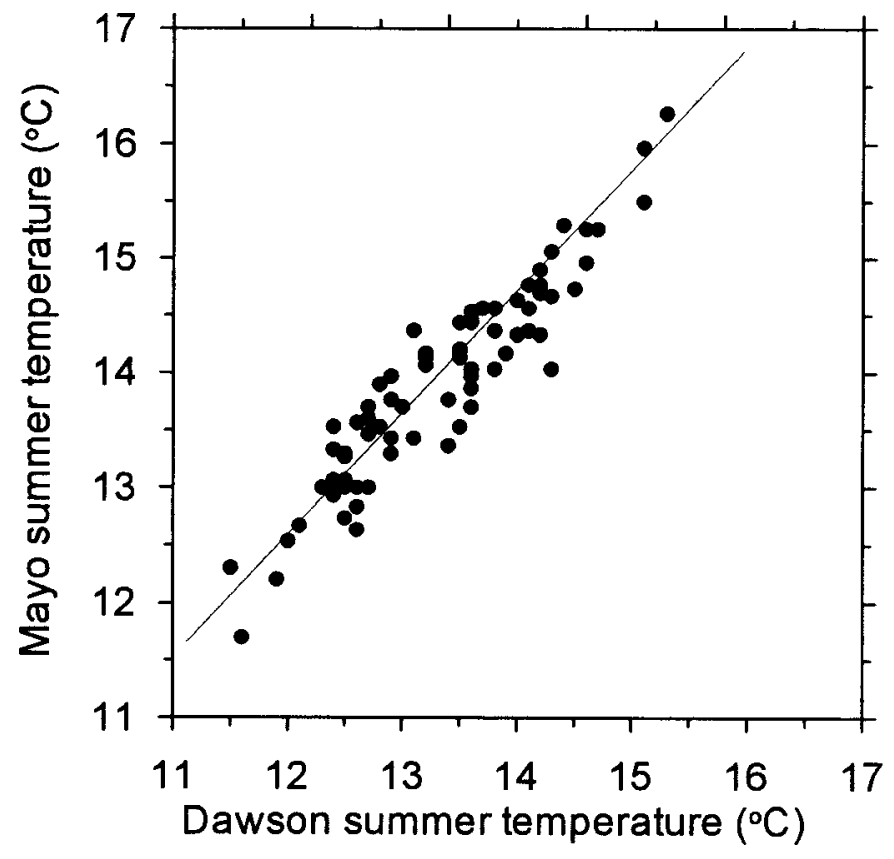

FIG 2. Mean summer temperature $\left({ }^{\circ} \mathrm{C}\right)$ at Dawson $\left(\mathrm{D}_{\mathrm{t}}\right)$ and Mayo $\left(\mathrm{M}_{\mathrm{t}}\right)$. The principal axis is $\mathrm{M}_{\mathrm{t}}=1.04 \mathrm{D}_{\mathrm{t}}+0.12, \mathrm{r}^{2}=0.88$. Data for $1925-2000$ from Meteorological Service of Canada (2002).

paper birch (Betula papyrifera), and willows (Salix spp.). Lesser amounts of lodgepole pine (Pinus contorta), balsam poplar (Populus balsamifera), and aspen (Populus tremuloides) are present (Environment Canada, 2001). Toward the north, forest stands become increasingly open, and individual trees are shorter.

\section{FIRE WEATHER INDICES}

The likelihood of ignition and potential size of a fire depend on the prevailing moisture content of the fuel, which is largely a function of the antecedent weather (Anderson et al., 2000). During the fire season in Canada, the Fire Weather Index (FWI), a daily measure of potential fire danger, is calculated from measurements of temperature, precipitation, relative humidity, and wind speed

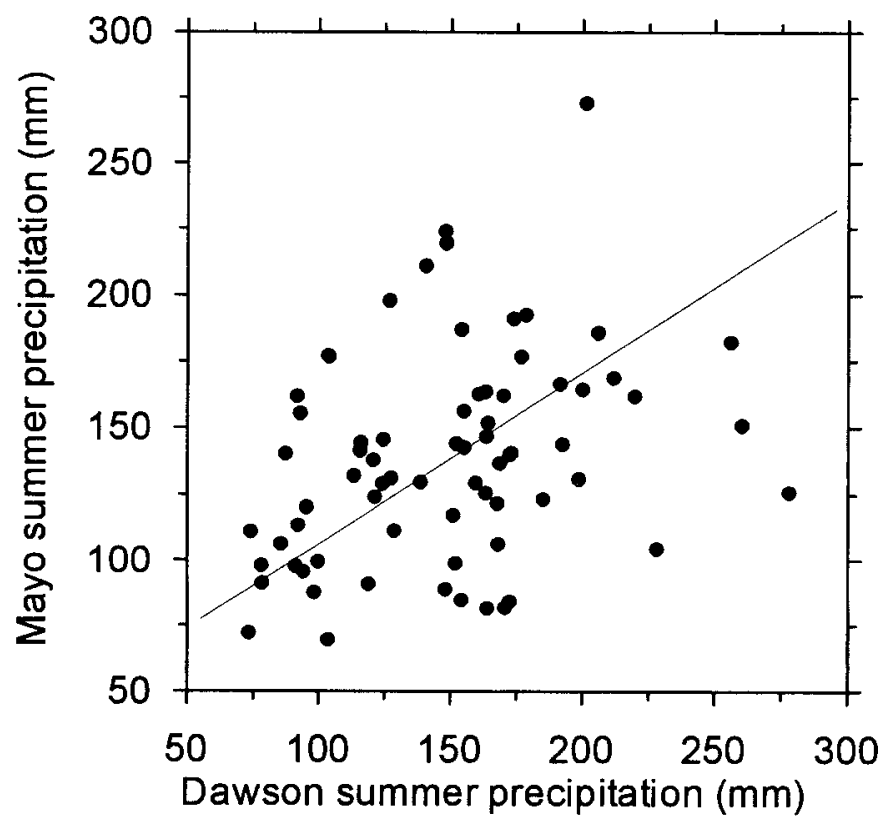

FIG. 3. Total summer precipitation $(\mathrm{mm})$ at Dawson $\left(\mathrm{D}_{\mathrm{p}}\right)$ and Mayo $\left(\mathrm{M}_{\mathrm{p}}\right)$. The principal axis is $M_{p}=0.66 D_{p}+41.27, r^{2}=0.10$. Data for $1926-2000$ from Meteorological Service of Canada (2002).

(Van Wagner, 1987). The FWI is used to predict the intensity and potential spread of fire, largely by estimating the state of forest fuels. The FWI is also used to estimate the fire hazard warning that is commonly posted in northern communities. A Daily Severity Rating (DSR) is calculated from the FWI with Equation 41 of Van Wagner (1987):

$$
\mathrm{DSR}=0.0272(\mathrm{FWI})^{1.77}
$$

The purpose of the DSR is to weight the FWI to improve estimates of the effort required to control a fire under different conditions (Van Wagner, 1987). By averaging DSRs over a period, one can obtain a Seasonal Severity Rating (SSR), which can be used as an index of fire weather variation from season to season (Van Wagner, 1987). 


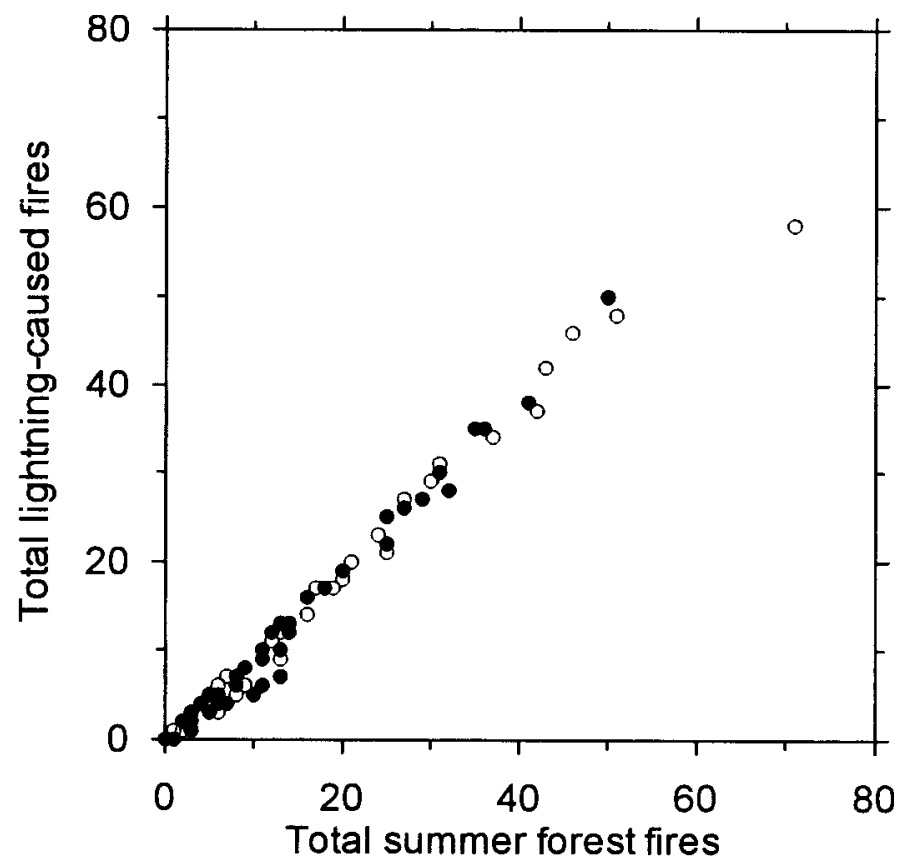

FIG 4. Total forest fires $\left(\mathrm{M}_{\mathrm{t}}, \mathrm{D}_{\mathrm{tf}}\right)$ and lightning-caused fires $\left(\mathrm{M}_{\mathrm{lf}}, \mathrm{D}_{\mathrm{lf}}\right)$, recorded in summer 1960 to 2000 in Mayo $(\bullet)$ and Dawson (o) districts. The principal axes of the data are $\mathrm{M}_{\mathrm{lf}}=0.99 \mathrm{M}_{\mathrm{tf}}-1.48, \mathrm{r}^{2}=0.99$ for Mayo and $\mathrm{D}_{\mathrm{lf}}=0.93\left(\mathrm{D}_{\mathrm{tf}}\right)$ $-0.36, \mathrm{r}^{2}=0.98$ for Dawson.

\section{DATA}

Yukon Fire Management records fire activity, fire danger, and fire weather for 10 fire management districts in the Yukon Territory (Fig. 1). Complete records exist from 1960, and the data we used for analysis are from 1960 to 2000. For each fire, the date of initiation, size, cause, and action taken are documented. Fire danger ratings, such as the SSR, are also recorded, but these were available only until 1998. For clarity in definition, we considered only fires recorded during the summer, which form the bulk of the record from the Dawson and Mayo districts (Table 1).

\section{Fire Regime}

The fire regimes of the two districts are similar. Between 1960 and 2000, the mean number of lightningignited fires per summer was 18 in the Dawson district and 14 in the Mayo district. The mean area burned each summer was $208 \mathrm{~km}^{2}$ in Dawson and $228 \mathrm{~km}^{2}$ in Mayo. The maximum number of fires recorded in a summer was 58 in Dawson (1986) and 50 in Mayo (1983). The most extensive area burned by a single fire was $1288 \mathrm{~km}^{2}$ in Dawson (1966) and $1190 \mathrm{~km}^{2}$ in Mayo (1998). The relative proportion of the fires ignited by lightning has been constant throughout the record at $85 \%$ (Table 1, Fig. 4). The area burned by unfought fires as a proportion of the entire area burned each summer is also well defined for all but four years (Fig. 5); this proportion is $73 \%$ for Mayo, $65 \%$ for Dawson, and 69\% overall. To reduce the impact of human factors on correlations between the fire and climate records,

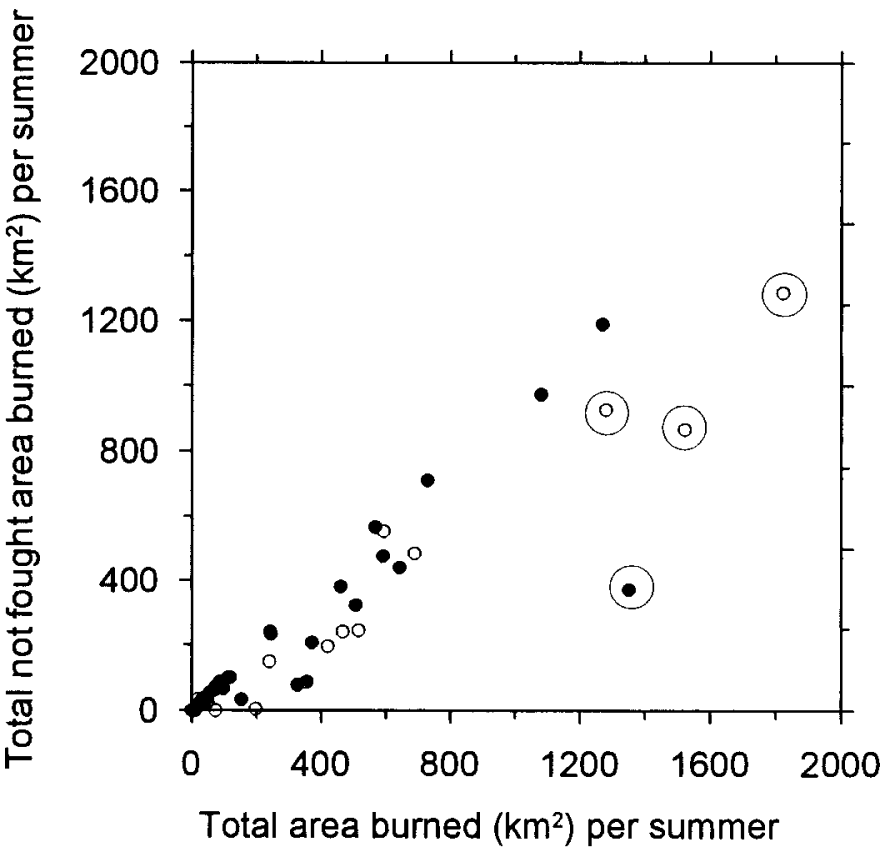

FIG. 5. Total area burned $\left(\mathrm{M}_{\mathrm{ta}}, \mathrm{D}_{\mathrm{ta}}, \mathrm{km}^{2}\right)$ and unfought area burned $\left(\mathrm{M}_{\mathrm{ua}}, \mathrm{D}_{\text {ua }}\right.$ $\mathrm{km}^{2}$ ) per summer, 1960 to 2000 in Mayo (•) and Dawson (o) fire management districts. Outlying values are circled. The principal axes, without considering outlying values, are $\mathrm{M}_{\mathrm{ua}}=0.90 \mathrm{M}_{\mathrm{ta}}-19.35, \mathrm{r}^{2}=0.96$ for Mayo, and $\mathrm{D}_{\mathrm{ua}}=0.68 \mathrm{D}_{\mathrm{ta}}$ $-5.04, \mathrm{r}^{2}=0.89$ for Dawson.

we analyzed only fires that were started by lightning and only the annual area burned by unfought fires.

Almost all of the fires in central Yukon that were not fought between 1960 and 2000 were ignited by lightning, in total accounting for over $99 \%$ of the area burned by unfought fires. However, several of the fought fires were also ignited by lightning. For data from both districts combined, unfought fires ignited by lightning accounted for $69 \%$ of the total area burned by lightning-ignited fires. It is impossible to determine the additional area that would have been burned had all lightning-ignited fires been allowed to burn freely; however, the total area burned by lightning-ignited fires in the two districts between 1960 and 2000 was $18420 \mathrm{~km}^{2}$, for an average of $450 \mathrm{~km}^{2} / \mathrm{yr}$, or $432 \mathrm{~km}^{2} /$ summer. Since substantial tracts of the region are mountainous and extend above the tree line, the total forest area in the districts is considerably less than the area of the districts themselves. Yukon Fire Management estimates that forest occupies approximately $95000 \mathrm{~km}^{2}$, or $60 \%$, of the $160000 \mathrm{~km}^{2}$ in the two districts (A. Beaver, pers. comm. 2004). From these data, the fire cycle in central Yukon is estimated at approximately 210 years. This estimate is approximate because data on annual area burned include small areas left unburned within a fire perimeter, mapping of forest area excludes recently burned terrain, and fire suppression reduces the potential area burned.

\section{Climate}

Temperature and precipitation data for Mayo were obtained directly from the Meteorological Service of Canada, 
and data for Dawson were obtained from the Historical Canadian Climate Database (Meteorological Service of Canada, 2002). Daily observations of relative humidity and wind speed were included in the fire database obtained from Yukon Fire Management. The temperature record for Mayo is continuous from 1925, and the precipitation record, except for 1995, from 1926 to 2000 . While temperatures have been recorded at Dawson since 1898 and precipitation since 1902, both records were available only until 1999. Complete relative humidity and wind speed records for both Dawson and Mayo were obtained for 1960 to 1998 .

\section{Climate Change}

GCMs are the tool most commonly used to project future climate. Environment Canada supplies climate projections from eight GCMs through its Canadian Climate Impacts and Scenarios (CCIS) Project (www.cics.uvic.ca/ scenarios). The models include those of the Canadian Center for Climate Modeling and Analysis (CGCM1, CGCM2), the UK Hadley Center for Climate Prediction and Research (HadCM2), the German Climate Research Center (Echam4), the Geophysical Fluid Dynamics Laboratory (GFDL-R15), the Australian Commonwealth Scientific and Industrial Research Organization (CSIRO-Mk2b), and the Japanese Center for Climate System Research (CCSR-98).

Twenty-nine different scenarios for future climate in Yukon have been provided by the Canadian Institute for Climate Studies (CICS) from these eight models, with variations in simulated effects of greenhouse gases, aerosols, and other radiatively active components of the atmosphere. Data on mean temperature, total precipitation, mean relative humidity, and mean wind speed are available monthly. Baseline data are intended to represent conditions in 1961-90, while projections-expressed as an absolute or percent change from the baseline, depending on the climate variable - are given for 2010 - 39 and 204069. Climate scenarios are also available for 2070-99, but we regard this as too distant in time for the results to be useful for policy or management. Bonsal et al. (2003) have examined the baseline climate simulated by these GCMs for the western Cordillera of Canada, including Yukon Territory. The observed mean temperature field for the region in 1961-90 is well represented by the models; however, most of the models overestimate precipitation.

\section{METHODS}

Since a primary goal of this paper is to quantify the relations between climate and forest-fire variables for central Yukon as a whole, we combined the number of summer forest fires ignited by lightning and the area burned per summer by unfought fires in both districts. SSR data were analyzed separately for each district, since these values are directly derived from weather data for Dawson and Mayo.

Spearman's rank correlation coefficient, $r_{s}$, a nonparametric measurement of association, was used to determine the strength of the statistical relations between records of mean summer temperature, total precipitation, wind speed, and relative humidity from Mayo and Dawson and summer fire occurrence, area burned, and SSR (Hammond and McCullagh, 1978). Parametric relations between these variables were obtained by least-squares linear regression, with forest-fire data transformed to ensure a normal distribution of the resulting residuals. Several positive transformations of the data were assessed in terms of the skewness and kurtosis of the residuals from the fitted least-squares linear regression lines. The transformed variables that produced residuals with skewness and kurtosis closest to normal were retained for further correlation analyses. To obtain satisfactory relations, forest-fire occurrence data were transformed by square root; area burned, by fourth root; and SSR, by cube root. The significance levels for these correlations were obtained by two-tailed Student's ttest. The Pearson product-moment correlation coefficient, $r_{p}$, and the coefficient of determination, $r^{2}$, were calculated for the transformed variables.

The statistical relations to be used in forecasting were obtained by bivariate and stepwise multiple regression of climate variables against each forest-fire variable, using SPSS Base 8.0. The significance of these models was obtained by evaluating the coefficient of multiple correlation, $\mathrm{R}$, and the adjusted coefficient of multiple determination, $R^{2}$, and by testing the calculated value of $F$, derived from the regression coefficient, against the critical value in the F-distribution (Hammond and McCullagh, 1978). The adjusted $R^{2}$ is a function of $R^{2}$, adjusted by the number of variables in the regression model and the sample size, which estimates how well the derived multiple regression line would fit another sample drawn from the same population (Norusis, 1999). The standard error of the estimate was used to obtain a $95 \%$ confidence interval for the forecast.

\section{Climate Modeling}

The outputs from 29 GCM scenarios available through CICS were examined for central Yukon. For each climate variable, the scenarios with highest and lowest projected changes for the summers of 2040-69 were selected for further use (Table 2) to include the greatest range in projections of future climate. One scenario (CGCM1-GA3) projected both the lowest total summer precipitation and the lowest average summer wind speed. As a result, seven scenarios were used for projecting changes in climate and subsequent changes in the forest-fire regime (Table 2).

Future climate scenarios for 2010-39 and 2040-69 were created for central Yukon by adding the projected changes to recorded 1961-90 summer climates. Since each projected time period contains projections for 30 
TABLE 2. Scenarios chosen for climate projections.

\begin{tabular}{lll}
\hline \hline & \multicolumn{1}{c}{ Highest } & \multicolumn{1}{c}{ Lowest } \\
\hline Temperature & CGCM1-GA1 $^{1}$ & HadCM2-GA1 \\
Precipitation & HadCM2-GG3 $^{2}$ & CGCM1-GA3 \\
Relative Humidity & Echam4-GG1 $^{4}$ & HadCM2-GAX $^{5}$ \\
Wind Speed & CCSR98-GA1 $^{1}$ & CGCM1-GA3 $^{3}$ \\
\hline
\end{tabular}

${ }^{1} \mathrm{GA} 1=$ greenhouse gas with aerosol simulation 1.

${ }^{2} \mathrm{GG} 3$ = greenhouse gas simulation 3 .

${ }^{3} \mathrm{GA} 3=$ greenhouse gas with aerosol simulation 3 .

${ }^{4} \mathrm{GG} 1=$ greenhouse gas simulation 1.

${ }^{5} \mathrm{GAX}=$ greenhouse gas with aerosol ensemble-mean simulation.

years, and seven scenarios were used for each projection, we obtained a total of 210 values for each climate variable during each time period. The projected climate variables were incorporated into the selected multiple regression models and used to estimate the highest, lowest, and mean future fire occurrence, area burned, and SSR for both periods. The highest and lowest values within the 210 projected values were identified by inspection. A $95 \%$ confidence interval for the mean projections in each period was determined with two standard errors of the estimate. Since the regression equations used transformed forestfire variables, and the results were converted back to their original units for reporting, the confidence intervals are not symmetrical with respect to the mean. The variability of the future regime was estimated in a similar manner, by obtaining the ranges of fire occurrence and area burned for each of the seven scenarios in the respective time periods. The analysis of variability is limited because the projected climatic variability remains identical to that of the 196190 record. Therefore, forecast changes in variability are only a product of nonlinearities in the derived relations between climate and fire incidence; they do not reflect changes in variability that might be expected to result from changing climate variability.

\section{Assumptions}

The statistical nature of this investigation assumes several aspects of the relations between forest fires and climate. These are critical for appraisal of the results, and are stated explicitly.

1. The statistical methods do not require a physical basis for the associations between climate and forest fires. However, documented causal relations between weather and fire behaviour indicate that such associations have physical significance (Van Wagner, 1987).

2. The climate data are collected at two points in a large, physiographically diverse region and are unlikely to be entirely representative of conditions in the area. However, the high correlation of the temperature records from Dawson and Mayo (Fig. 2) indicates that in this aspect, the region appears relatively homogeneous, while the precipitation field is more diverse.
3. The analysis assumes that there has been no significant change in fire detection or management throughout the period of record. Although the technology for detection and suppression of fire has improved since 1960, and may do so in the future, no correction for such changes has been made.

4. The predictions assume that fire behaviour has not been and will not be constrained by fuel supply. Ultimately, this assumption may be invalid if the fire regime intensifies so that the fire cycle shortens and large portions of the study area are recently burned. However, since only about $10 \%$ of the forested terrain has burned in the last 40 years, over the time scale of interest the assumption is likely valid.

5. The analysis assumes that the relations between fire and climate will remain constant under climate warming: in particular, that there are no cumulative impacts of climate change on the fire regime that may alter the physical basis of the associations between climate and forest-fire variables. For instance, changes in forestspecies composition that follow climate change and alter fire behaviour are not considered. Climate-fire relations have been altered in the past as the climate has changed (Larsen, 1997; Johnson et al., 1999). At this stage, however, information on such past changes from the study area or adjacent areas (e.g., Yarie, 1981) is insufficient to render these effects tractable.

\section{RESULTS}

\section{Climate-Fire Regime Relations}

Table 3 presents the Spearman rank correlation coefficients for the associations of climate and forest-fire variables from central Yukon. Of the indices examined, the incidence of lightning-ignited fires is most strongly correlated with regional temperatures. The relations are positive because hot weather creates the conditions associated with lightning. Conversely, the relations between total precipitation and fire occurrence are negative, as the combustibility of the forest is reduced by rainfall. The strongest associations for relations between area burned and climate are with moisture-related variables (Table 3). Area burned, like fire occurrence, is positively correlated with temperature. SSR is more highly correlated with the availability of moisture, via either precipitation or relative humidity, than with temperature at Mayo and Dawson (Table 3 ). In combination, these data suggest that moisture plays the most important meteorological role in determining fire severity in the study area.

The Pearson product-moment correlation coefficients for relations between climate variables and transformed fire data for central Yukon are similar to the Spearman rank analyses in significance and strength (Table 4). The relations between most climate variables and fire occurrence for the central Yukon region were statistically 
TABLE 3. Spearman rank correlation coefficients, $r_{s}$, for relation between summer climate variables and fire variables in the central Yukon. Correlations with SSR shown for Dawson and Mayo.

\begin{tabular}{|c|c|c|c|c|c|c|c|c|c|}
\hline & \multicolumn{3}{|c|}{ Forest-fire Occurrence } & \multicolumn{3}{|c|}{ Area Burned } & \multicolumn{3}{|c|}{ SSR } \\
\hline & $r_{s}$ & $p$ & $\mathrm{n}$ & $r_{s}$ & $p$ & $\mathrm{n}$ & $r_{s}$ & $p$ & $\mathrm{n}$ \\
\hline \multicolumn{10}{|l|}{ Dawson: } \\
\hline Mean Temperature & 0.54 & $<0.001$ & 40 & 0.52 & 0.001 & 40 & 0.13 & 0.427 & 39 \\
\hline Total Precipitation & -0.52 & $<0.001$ & 40 & -0.68 & $<0.001$ & 40 & -0.77 & $<0.001$ & 39 \\
\hline Mean Relative Humidity & -0.43 & 0.007 & 39 & -0.63 & $<0.001$ & 39 & -0.88 & $<0.001$ & 39 \\
\hline Mean Wind Speed & -0.41 & 0.010 & 39 & -0.17 & 0.292 & 39 & 0.15 & 0.337 & 39 \\
\hline \multicolumn{10}{|l|}{ Mayo: } \\
\hline Mean Temperature & 0.52 & $<0.001$ & 41 & 0.54 & $<0.001$ & 41 & 0.38 & 0.016 & 39 \\
\hline Total Precipitation & -0.27 & 0.095 & 40 & -0.46 & 0.003 & 40 & -0.81 & $<0.001$ & 38 \\
\hline Mean Relative Humidity & -0.36 & 0.02 & 39 & -0.59 & $<0.001$ & 39 & -0.85 & $<0.001$ & 39 \\
\hline Mean Wind Speed & -0.51 & 0.001 & 39 & -0.23 & 0.162 & 39 & -0.07 & 0.690 & 39 \\
\hline
\end{tabular}

TABLE 4. Pearson product-moment correlation coefficients, $r_{p}$, for relations between climate variables and fire variables (forest-fire occurrence and area burned) in the central Yukon. Correlations with SSR are shown for Dawson and Mayo.

\begin{tabular}{|c|c|c|c|c|c|c|c|c|c|}
\hline & \multicolumn{3}{|c|}{ Forest-fire Occurrence } & \multicolumn{3}{|c|}{ Area Burned } & \multicolumn{3}{|c|}{ SSR } \\
\hline & $r_{p}$ & $p$ & $\mathrm{n}$ & $r_{p}$ & $p$ & $\mathrm{n}$ & $r_{p}$ & $p$ & $\mathrm{n}$ \\
\hline \multicolumn{10}{|l|}{ Dawson: } \\
\hline Mean Temperature & 0.58 & $<0.001$ & 40 & 0.58 & $<0.001$ & 40 & 0.15 & 0.370 & 39 \\
\hline Total Precipitation & -0.51 & 0.001 & 40 & -0.61 & $<0.001$ & 40 & -0.80 & $<0.001$ & 39 \\
\hline Mean Relative Humidity & -0.43 & 0.006 & 39 & -0.59 & $<0.001$ & 39 & -0.88 & $<0.001$ & 39 \\
\hline Mean Wind Speed & -0.47 & 0.002 & 39 & -0.27 & 0.097 & 39 & 0.11 & 0.502 & 39 \\
\hline \multicolumn{10}{|l|}{ Mayo: } \\
\hline Mean Temperature & 0.54 & $<0.001$ & 41 & 0.57 & $<0.001$ & 41 & 0.35 & 0.031 & 39 \\
\hline Total Precipitation & -0.25 & 0.119 & 40 & -0.42 & 0.007 & 40 & -0.76 & $<0.001$ & 38 \\
\hline Mean Relative Humidity & -0.39 & 0.014 & 39 & -0.56 & $<0.001$ & 39 & -0.85 & $<0.001$ & 39 \\
\hline Mean Wind Speed & -0.54 & $<0.001$ & 39 & -0.25 & 0.132 & 39 & -0.06 & 0.701 & 39 \\
\hline
\end{tabular}

significant at the 0.05 level, the highest $r_{p}$ occurring with mean summer temperature (Table 4). All climate variables, with the exception of wind speed, also had statistically significant relations to area burned at the 0.05 level. The highest $r_{p}$ for climate and area burned is with precipitation, and the association is negative. The values of $r_{p}$ for SSR and climate were also similar to the corresponding values for $r_{s}$. At Mayo, mean summer temperature, total summer precipitation, and relative humidity were related to SSR at the 0.05 significance level, but at Dawson, only the relations between total summer precipitation and relative humidity and SSR were statistically significant (Table 4).

Comparison of the results in Tables 3 and 4 indicates that the climate record from Dawson is more closely associated with the regional forest-fire regime than the record from Mayo. In consequence, the Dawson climate record was used to define the relations with fire occurrence and area burned in central Yukon for projection of the fire regime.

Step-wise multiple regression, to obtain the climate variables and their coefficients for these projections, selected a moisture-related variable in each of the four models (Table 5). Both temperature and precipitation were selected for predicting forest-fire occurrence and area burned, but precipitation alone was selected for predicting SSR at Dawson, and relative humidity and wind speed were used for SSR at Mayo (Table 5).

\section{Future Climate Change in Central Yukon}

Table 6 shows the changes projected by the seven GCM scenarios that we considered. All seven project warmer summer temperatures over the next century. Most project an increase in precipitation from the baseline, but two project small decreases in 2010-39, and one, a decrease in 2040-69. Four of the seven scenarios project a decrease in relative humidity by $2040-69$. Although precipitation is projected to rise, this increase is offset by the increase in summer temperature, leading to a decline in humidity. The projected changes in wind speed are small for all scenarios in both time periods.

\section{Future Forest-Fire Regime in Central Yukon}

For all forest-fire variables, the projections indicate that the fire regime in central Yukon will continue to vary from year to year, but that, overall, the occurrence and extent of forest fires may increase (Table 7). From climate scenarios projecting little change, the projections of lowest annual fire occurrence remain close to the present level. For 2010-39, a minimum of two fires per summer is projected for central Yukon, which is higher than at present, but other scenarios imply that the maximum number of fires per year will increase, potentially by about $60 \%$. By 2069 , the $95 \%$ confidence interval for the mean number of 
TABLE 5. Regression equations used for projecting future forest-fire regime. ${ }^{1}$

\begin{tabular}{|c|c|c|c|}
\hline Projection Equations & Adjusted $\mathrm{R}^{2}$ & Significance $(\mathrm{F})$ & SE (estimate) \\
\hline$(\text { Fire Occurrence })^{0.5}=1.28 \mathrm{D}_{\mathrm{t}}-0.02 \mathrm{D}_{\mathrm{p}}-9.32$ & 0.41 & $<0.001$ & 1.80 \\
\hline (Area Burned) $)^{0.25}=2.51 \mathrm{D}_{\mathrm{t}}-0.07 \mathrm{D}_{\mathrm{p}}-13.60$ & 0.52 & $<0.001$ & 3.75 \\
\hline$(\text { SSR at Dawson })^{0.33}=-0.004 D_{n}+1.77$ & 0.62 & $<0.001$ & 0.13 \\
\hline$(\mathrm{SSR} \text { at Mayo })^{0.33}=-0.05 \mathrm{M}_{\mathrm{rh}}+0.05 \mathrm{M}_{\mathrm{ws}}+3.5$ & 0.79 & $<0.001$ & 0.11 \\
\hline
\end{tabular}

${ }^{1} \mathrm{D}_{\mathrm{t}}=$ mean summer temperature at Dawson; $\mathrm{D}_{\mathrm{p}}=$ total summer precipitation at Dawson; $\mathrm{M}_{\mathrm{rh}}=$ average summer relative humidity at Mayo; $\mathrm{M}_{\mathrm{ws}}=$ average summer wind speed at Mayo.

TABLE 6. Projected changes in mean summer temperature, total summer precipitation, mean relative humidity, and mean wind speed for climate change scenarios. Maximum and minimum values for each variable in each time period are in boldface.

\begin{tabular}{|c|c|c|c|c|c|c|c|c|}
\hline & \multicolumn{2}{|c|}{ Temperature $\left({ }^{\circ} \mathrm{C}\right)$} & \multicolumn{2}{|c|}{ Precipitation $(\%)$} & \multicolumn{2}{|c|}{ Relative Humidity (\%) } & \multicolumn{2}{|c|}{ Wind Speed $(\%)$} \\
\hline & $2010-39$ & $2040-69$ & $2010-39$ & $2040-69$ & $2010-39$ & $2040-69$ & $2010-39$ & $2040-69$ \\
\hline HadCM2-GA1 & +1.0 & +1.3 & +11.5 & +15.8 & -0.5 & -2.2 & +0.0 & +0.9 \\
\hline HadCM2-GAX & +1.1 & +1.6 & -0.4 & +7.4 & -4.0 & -0.5 & -0.9 & -0.4 \\
\hline HadCM2-GG3 & +0.7 & +1.5 & +14.4 & +18.4 & +1.0 & +0.2 & -0.2 & +0.4 \\
\hline CGCM1-GA1 & +1.8 & +3.2 & +6.0 & +9.3 & -1.0 & -0.9 & +0.1 & +0.3 \\
\hline CGCM1-GA3 & +1.7 & +3.1 & - 3.9 & -1.0 & -3.3 & -5.8 & +0.1 & +0.2 \\
\hline Echam4-GG1 & +1.4 & +2.6 & +11.5 & +18.0 & +1.4 & +0.3 & +0.8 & +1.2 \\
\hline CSR98-GA1 & +1.5 & +2.8 & +7.5 & +15.3 & +4.2 & +3.4 & +0.3 & +1.2 \\
\hline
\end{tabular}

fires each year ranges to potentially four times the present level. The range of fire occurrences projected by individual models for each forecast period increases slightly with time, but remains less than the range observed between 1960 and 2000.

The projections for area burned (Table 7) follow a similar pattern. Minimum projections of annual area burned remain zero over the next century, while the highest projections indicate substantial increases in annual area burned by mid century. The minimum area burned is projected to be zero, but the minimum number of fires is not, because different statistical models were used to project these fire variables from the same climatic regimes. The $95 \%$ confidence intervals for mean area burned in the future range from less than the current mean to more than seven times the current mean by $2040-69$. The range in area burned projected by individual models also increases by about $20 \%$, from a mean comparable to the present range.

Seasonal Severity Ratings (Table 8) are not projected to change. At Dawson, the projected SSRs are lower than present values. The reason is the low coefficient for $D_{p}$ in the model, which minimizes the sensitivity of the model to climatic change. At Mayo, the maxima for SSR are greater than present for all projections, while the minimum projections are lower than for the present.

Several scenarios of climate for the 21 st century imply that forest-fire frequency and the area burned in central Yukon will increase with climate change. Although the lowest projections for fire occurrence, area burned, and SSR for this century resemble the levels presently recorded, the highest projections greatly exceed current conditions, and as a result the mean projection increases. This increase is a function of the differences in climate changes projected for the region by the GCMs used. Since the scenarios were built using a specified variability in climate, the interannual range in number of fires is not predicted to rise greatly, but the range of area burned may increase by $20 \%$.

A major climatic factor driving these projections is moisture, as recorded by total summer precipitation and average summer relative humidity. This is problematic for planning and management, since projections of future precipitation are generally regarded with less confidence than those for temperature, given that the GCMs considered do not reproduce the present precipitation field in the region as well as the present distribution of temperature (Bonsal et al., 2003).

\section{Note Added After Review}

In summer 2004, the Dawson and Mayo districts experienced the most extensive fire season on record. In central Yukon, $6583 \mathrm{~km}^{2}$ burned-more than three times the total area burned $\left(1984 \mathrm{~km}^{2}\right)$ in the previous record summer, 1998 (Yukon Fire Management, pers. comm. 2005).

\section{ACKNOWLEDGEMENTS}

This work was supported by the Village of Mayo, through the Community Development Fund; the Government of Yukon; the Northern Climate ExChange; and the NSERC Northern Chair at Carleton University. We thank the community of Mayo for encouragement and hospitality; J.V. Clark School and the Mayo Community Learning Centre, Yukon College, for use of facilities; and Michael McGinnis, for accommodation. David Milne, Wildfire Prevention Coordinator of Yukon Fire Management, kindly provided 
TABLE 7. Projections for fire occurrence (number of fires per summer) $)^{1}$ and area burned per summer by unfought fires ${ }^{2}\left(\mathrm{~km}^{2}\right)$ in central Yukon.

\begin{tabular}{|c|c|c|c|c|c|c|}
\hline & $\begin{array}{l}\text { Absolute } \\
\text { Highest }\end{array}$ & $\begin{array}{l}\text { Absolute } \\
\text { Lowest }\end{array}$ & $\begin{array}{l}\text { Overall } \\
\text { Mean }\end{array}$ & $\begin{array}{l}95 \% \text { Confidence } \\
\text { Interval for Mean }\end{array}$ & $\begin{array}{l}\text { Mean Range in } \\
\text { Fire Occurrence }\end{array}$ & $\begin{array}{c}\text { Range } \\
\text { of Ranges }\end{array}$ \\
\hline \multicolumn{7}{|c|}{ Fire Occurrence: } \\
\hline $1960-2000$ & 93 & 0 & 30 & - & - & - \\
\hline $2010-2039$ & 117 & 2 & 38 & $97-7$ & 55 & 10 \\
\hline $2040-2069$ & 156 & 4 & 53 & $119-14$ & 58 & 9 \\
\hline \multicolumn{7}{|c|}{ Area Burned by Unfought Fires: } \\
\hline $1960-2000$ & 1530 & 0 & 307 & & & \\
\hline $2010-2039$ & 2947 & 0 & 222 & $1531-50$ & 1488 & 541 \\
\hline $2040-2069$ & 5006 & 0 & 407 & $2251-190$ & 1735 & 751 \\
\hline
\end{tabular}

${ }^{1}$ Projections are for lightning-ignited fires, which historically have been about $85 \%$ of all fires (Table 1).

${ }^{2}$ Projections were derived from statistics relating to unfought fires, which historically have accounted for about $70 \%$ of the total area burned.

${ }^{3}$ Mean of the ranges in fire occurrence or area burned per summer under seven climate scenarios.

TABLE 8. Seasonal Severity Rating projections for Dawson and Mayo fire management districts.

\begin{tabular}{lcccc}
\hline \hline & $\begin{array}{c}\text { Absolute } \\
\text { Highest }\end{array}$ & $\begin{array}{c}\text { Absolute } \\
\text { Lowest }\end{array}$ & Mean & $\begin{array}{c}\text { 95\% Confidence } \\
\text { Interval for Mean }\end{array}$ \\
\hline Dawson: & & & & \\
1960-2000 & 5.2 & 0.5 & 1.9 & $2.5-0.6$ \\
2010-2039 & 3.2 & 0.2 & 1.3 & $2.5-0.6$ \\
2040-2069 & 3.2 & 0.2 & 1.3 & \\
Mayo: & & & & $2.9-0.9$ \\
1960-2000 & 5.7 & 0.5 & 2.0 & $2.9-0.9$ \\
2010-2039 & 6.1 & 0.2 & 1.7 & 1.7 \\
$2040-2069$ & 8.0 & 0.2 & & \\
\hline \hline
\end{tabular}

the fire data. K. Gajewski and M.F. Fox critically examined the thesis from which this paper has developed.

\section{REFERENCES}

ANDERSON, K., MARTELL, D.L., FLANNIGAN, M.D., and WANG, D. 2000. Modeling of fire occurrence in the boreal forest region of Canada. In: Kasischke, E.S., and Stocks, B.J., eds. Fire, climate change and carbon cycling in the boreal forest. New York: Springer-Verlag. 357-367.

BERGERON, Y., and ARCHAMBAULT, S. 1993. Decreasing frequency of forest fires in the southern boreal zone of Quebec and its relation to global warming since the end of the 'Little Ice Age.' Holocene 3:225-259.

BONSAL, B.R., PROWSE, T.D., and PIETRONIRO, A. 2003. An assessment of global climate model-simulated climate for the western cordillera of Canada (1961-90). Hydrological Processes 17(18):3703-3716.

BOURGEAU-CHAVEZ, L.L., KASISCHKE, E.S., MUDD, J.P., and FRENCH, N.H.F. 2000. Distribution of forest ecosystems and the role of fire in the North American boreal region. In: Kasischke, E.S., and Stocks, B.J., eds. Fire, climate change and carbon cycling in the boreal forest. New York: Springer-Verlag. $111-131$.
ENVIRONMENTCANADA. 2001. Terrestrial ecozones of Canada. www.ec.gc.ca/soer-ree/English/Framework/NarDesc/ canada_e.cfm. Accessed 15 April 2005.

- 2002. Canadian climate normals, 1971-2000. www. climate.weatheroffice.ec.gc.ca/climate_normals/. Accessed 15 April 2005.

FLANNIGAN, M.D., and VAN WAGNER, C.E. 1991. Climate change and wildfire in Canada. Canadian Journal of Forest Research 21:66-72.

HALLETT, D.J., and WALKER, R.C. 2000. Paleoecology and its application to fire and vegetation management in Kootenay National Park, British Columbia. Journal of Paleolimnology 24:401-414.

HAMMOND, R., and McCULLAGH, P.S. 1978. Quantitative techniques in geography. Oxford: Oxford University Press.

HENGEVELD, H.G. 1997. The science of climate change. In: Taylor, E., and Taylor, B., eds. Responding to global climate change in British Columbia and Yukon. Canada country study: Climate impacts and adaptation, Vol. 1. Downsview, Ontario: Atmospheric Environment Service, Environment Canada.

INTERGOVERNMENTAL PANEL ON CLIMATE CHANGE. 2001. Climate change 2001: Impacts, adaptations, and vulnerability: Contribution of Working Group II to the Third Assessment Report of the Intergovernmental Panel on Climate Change. Cambridge and New York: Cambridge University Press.

JOHNSON, E.A. 1992. Fire and vegetation dynamics: Studies from the North American boreal forest. Cambridge: Cambridge University Press.

JOHNSON, E.A., and VAN WAGNER, C.E. 1985. The theory and use of two fire history models. Canadian Journal of Forest Research 15:214-220.

JOHNSON, E.A., MIYANISHI, K., and O'BRIEN, N. 1999. Longterm reconstruction of the fire season in the mixedwood boreal forest of western Canada. Canadian Journal of Botany 77: $1185-1188$.

JOHNSTONE, J.F., CHAPIN, F.S., III, FOOTE, J., KEMMETT, S., PRICE, K., and VIERECK, L. 2004. Decadal observations of tree regeneration following fire in boreal forests. Canadian Journal of Forest Research 34:267-273. 
KASISCHKE, E.S. 2000. Boreal ecosystems in the global carbon cycle. In: Kasischke, E.S., and Stocks, B.J., eds. Fire, climate change and carbon cycling in the boreal forest. New York: Springer-Verlag. 19-30.

LARSEN, C.P.S. 1997. Spatial and temporal variations in boreal forest fire frequency in northern Alberta. Journal of Biogeography 24:663-673.

LYNCH, J.A., HOLLIS, J.L., and FENG, S.H. 2004. Climatic and landscape controls of the boreal forest fire regime: Holocene records from Alaska. Journal of Ecology 92:477-489.

MACKAY, J.R. 1995. Active layer changes (1968-1993) following the forest-tundra fire near Inuvik, NWT, Canada. Arctic and Alpine Research 27:323-336.

MAXWELL, B. 1997. Responding to global climate change in Canada's Arctic. Canada country study: Climate impacts and adaptation, Vol. 1. Downsview, Ontario: Atmospheric Environment Service, Environment Canada.

METEOROLOGICAL SERVICE OF CANADA. 2002. AHCCDAdjusted historical Canadian climate data, Version December 2002: Rehabilitated precipitation and homogenized temperature data sets. Climate Research Branch, Meteorological Service of Canada, Environment Canada. www.cccma.bc.ec.gc.ca/hccd/. Accessed 15 April 2005.

NASH, C.H., and JOHNSON, E.A. 1996. Synoptic climatology of lightning caused forest fires in subalpine and boreal forests. Canadian Journal of Forest Research 26:1859-1874.

NORUSIS, M.J. 1999. SPSS 9.0 guide to data analysis. Englewood Cliffs, New Jersey: Prentice Hall.

PAYETTE, S., MORNEAU, C., SIROIS, L., and DESPONTS, M. 1989. Recent fire history of the northern Québec biomes. Ecology 70:656-673.

SERREZE, M.C., WALSH, J.E., CHAPIN, F.S., III, OSTERKAMP, T., DYURGEROV, M., ROMANOVSKY, V., OECHEL, W.C., MORISON, J., ZHANG, T., and BARRY, R.G. 2000. Observational evidence of recent change in the northern highlatitude environment. Climatic Change 46:159-207.
STOCKS, B.J. 1991. The extent and impact of forest fires in northern circumpolar countries. In: Levine, J.S., ed. Global biomass burning: Atmospheric, climatic, and biospheric implications. Cambridge, Massachusetts: MIT Press. 197-202.

STOCKS, B.J., FOSBERG, M.A., LYNHAM, T.J., MEARNS, L., WOTTON, B.M., YANG, Q., JIN, J.-Z., LAWRENCE, K., HARTLEY, G.R., MASON, J.A., and McKENNEY, D.W. 1998. Climate change and forest fire potential in Russian and Canadian boreal forests. Climatic Change 38:1-13.

VAN CLEVE, K., CHAPIN, F.S., III, DYRNESS, C.T., and VIERECK, L.A. 1991. Element cycling in taiga forests: Statefactor control. BioScience 41:78-88.

VAN WAGNER, C.E. 1987. Development and structure of the Canadian Forest Fire Weather Index System. Ottawa: Canadian Forestry Service.

WAHL, H.E., FRASER, D.B., HARVEY, R.C., and MAXWELL, J.B. 1987. Climate of Yukon. Climatological Studies No. 40. Ottawa: Atmospheric Environment Service.

WARD, P.C., and MAWDSLEY, W. 2000. Fire management in the boreal forests of Canada. In: Kasischke, E.S., and Stocks, B.J., eds. Fire, climate change and carbon cycling in the boreal forest. New York: Springer-Verlag. 66-84.

WEBER, M.G., and STOCKS, B.J. 1998. Forest fires and sustainability in the boreal forests of Canada. Ambio 27: $545-550$.

WEIR, J.M.H., JOHNSON, E.A., and MIYANISHI, K. 2000. Fire frequency and the spatial age mosaic of the mixed-wood boreal forest in western Canada. Ecological Applications 10: $1162-1177$.

YARIE, J. 1981. Forest fire cycles and life tables: A case study from interior Alaska. Canadian Journal of Forest Research 11: $554-562$.

1983. Environmental and successional relationships of the forest communities of the Porcupine River drainage, interior Alaska. Canadian Journal of Forest Research 13:721-728.

YUKON BUREAU OF STATISTICS. 2000. Yukon annual statistical review: 1999. Whitehorse: Yukon Territorial Government Executive Council Office, Bureau of Statistics. 